\title{
Precious metal recoveries in secondary copper smelting with high-alumina slags
}

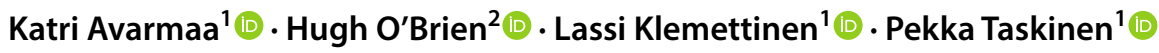

Received: 1 November 2018 / Accepted: 5 December 2019 / Published online: 31 December 2019

(c) The Author(s) 2019

\begin{abstract}
Waste electrical and electronic equipment (WEEE) represents a significant urban resource for precious metals. To maximize the recoveries and sustainable use of these metals, their behavior needs to be characterized in the secondary copper smelting of WEEE. The current study experimentally determined the distributions of gold, silver, platinum and palladium between copper alloy and $\mathrm{FeO}_{\mathrm{x}}-\mathrm{SiO}_{2}-\mathrm{Al}_{2} \mathrm{O}_{3} / \mathrm{FeO}_{\mathrm{x}}-\mathrm{SiO}_{2}-\mathrm{Al}_{2} \mathrm{O}_{3}-\mathrm{CaO}$ slags $\left(L^{\mathrm{Cu} / s}[M]=[\mathrm{M}]_{\text {Copper }} /[\mathrm{M}]_{\text {Slag }}\right)$ over the oxygen partial pressure range of $10^{-5}-10^{-10}$ atm at $1300^{\circ} \mathrm{C}$. In addition, the equilibria of copper alloy, slag and $\mathrm{Al}-\mathrm{Fe}$ spinel system are presented and discussed. The experiments were conducted employing an equilibration—drop-quenching technique followed by major element analysis with Electron Probe MicroAnalysis (EPMA) and trace element analysis with sensitive Laser Ablation Inductively Coupled Plasma Mass Spectrometry (LA-ICP-MS). The results showed that the distribution coefficient of silver increased from 10 to $10^{3}$ as a function of decreasing oxygen partial pressure. For gold, platinum and palladium, the distribution coefficients were at minimum $10^{5}$. Lime addition improved the recovery of silver notably and had a small positive effect on gold recovery into copper. Overall, the precious metals can be recovered very efficiently in copper alloy via secondary copper smelting with alumina-rich iron-silicate slags.
\end{abstract}

Keywords Sustainability $\cdot$ Recycling $\cdot$ Black copper $\cdot$ WEEE $\cdot$ LA-ICP-MS

\section{Introduction}

The most important industrial use of gold, silver and many PG-metals (platinum group) is in electrical and electronic equipment (EEE). Their quantities in EEE vary widely depending on the e-product, production era and location [1, 2]. In much of today's sophisticated electronic equipment, the precious metal concentrations are considerable, even up to several thousands of ppmw. Thus, end-of-life EEE (especially high-grade) provides much richer urban resources than the current primary ores for multiple precious and rare metals.

While the high demand for new electronics in the developing world has increased global sales remarkably, the rapid

Katri Avarmaa

katri.avarmaa@gmail.com

1 School of Chemical Engineering, Department of Chemical and Metallurgical Engineering, Aalto University, PO Box 16100, 00076 Aalto, Finland

2 Geological Survey of Finland, Vuorimiehentie 2, 02150 Espoo, Finland pace of innovations is making their lifespans shorter and disposal rates constantly higher. Therefore, WEEE presents one of the fastest-growing waste streams globally, with a growth rate of 3-5\% per year [3]. The presence of many precious and rare metals in WEEE makes it an attractive resource for recycling and secondary production. The production of precious metals from secondary resources has a lower environmental impact compared to primary production, and it implements sustainability targets with improved resource efficiency and securing the availability of precious metals.

The recovery of precious metals from the WEEE is currently performed in copper-making circuits including copper smelters, converters and secondary (black) copper smelters. Black copper smelting is typically implemented for low-grade copper scrap, which may be highly oxidized and includes a wide range of impurities, typically lead, tin, zinc, iron, nickel and aluminum $[4,5]$. Aluminum concentration in the copper scrap fraction varies from $1 \mathrm{up}$ to $10 \mathrm{wt} \%[6,7]$ depending on the initial WEEE composition and the shredding-sorting practices. The residual aluminum in secondary copper feed entering the furnace will have an influence on the slag properties and, therefore, on the success of the 
entire copper smelting process. The black copper smelting process includes reduction and oxidization smelting stages carried out in either order at the same furnace or consecutive furnaces, such as Ausmelt TSL (top submerged lance) $[8,9]$. This study focused on alumina-containing iron-silicate slags and shows how high-alumina (20 wt $\%$ ) and lime (5 wt $\%)$ concentrations in slag affect the precious metal behavior from reducing $\left(\mathrm{pO}_{2}=10^{-10} \mathrm{~atm}\right)$ to oxidizing atmospheres $\left(p O_{2}=10^{-5} \mathrm{~atm}\right)$.

In general, research concentrating on minor/trace element behavior in WEEE smelting is relatively sparse, as it is a new field of science, with no published studies of precious metal distributions between copper and high alumina-containing iron-silicate slag. We have recently published papers investigating rare elements In, Ga and Ge [10] and the PG-metal Ir [11] in secondary copper smelting with high-alumina slags. A review paper by Shuva et al. [12] collected the existing literature on minor element distributions in primary and secondary copper smelting. It shows that precious metal distributions in primary smelting with copper matte-slag systems have been investigated more broadly [13-18] than in secondary smelting between metallic copper and slag.

The purpose of the present study was to investigate the distribution behavior of gold, silver, platinum and palladium between molten copper alloy and alumina-containing iron-silicate slags in typical secondary copper smelting conditions, $p O_{2}=10^{-5}-10^{-10} \mathrm{~atm}$ and $T=1300^{\circ} \mathrm{C}$. The advanced experimental method consisted of equilibration and quenching followed by EPMA and LA-ICP-MS analyses. In our previous papers $[13,19,20]$, we have shown that the LA-ICP-MS technique can be utilized successfully for the analysis of the trace element contents in metallurgical slags based on true chemical dissolutions.

\section{Experimental section}

This study employed a static experimental technique, where data was collected after the system reached the true equilibrium. Technique consisted of three main stages: sample preparation, equilibration-drop-quenching (experiment) at controlled gas atmosphere and sample analyses.

\section{Sample preparation}

The copper master alloy was prepared by melting copper cathode (Boliden Harjavalta, 99.999\%) with approximately $1 \mathrm{wt} \%$ of each precious metal, silver (Alfa Aesar, 99.95\%), gold (Alfa Aesar, 99.95\%), platinum (Alfa Aesar, 99.98\%) and palladium (Alfa Aesar, 99.9\%), in an alumina crucible at $1400{ }^{\circ} \mathrm{C}$ and under $99 \% \mathrm{Ar}-1 \% \mathrm{H}_{2}$ gas atmosphere for $12 \mathrm{~h}$. The $\mathrm{CaO}$-free slag mixture was prepared from pure commercial powders of $\mathrm{Fe}_{2} \mathrm{O}_{3}$ (Alfa Aesar, 99.99\%), $\mathrm{SiO}_{2}$ (Umicore,
99.99\%) and $\mathrm{Al}_{2} \mathrm{O}_{3}$ (Sigma-Aldrich, 99.99\%). The components were weighed out to an initial composition of $52 \%$ of $\mathrm{Fe}_{2} \mathrm{O}_{3}$, $28 \%$ of $\mathrm{SiO}_{2}$ and $20 \%$ of $\mathrm{Al}_{2} \mathrm{O}_{3}\left(\mathrm{Fe} / \mathrm{SiO}_{2}=1.30\right)$. The slag forming components were thoroughly ground and mixed in an agate mortar to obtain a homogeneous slag powder mixture. The CaO-containing slag was prepared by adding $5 \mathrm{wt} \% \mathrm{CaO}$ (Sigma-Aldrich, 99.9\%) to the prepared $\mathrm{Fe}_{2} \mathrm{O}_{3}-\mathrm{SiO}_{2}-\mathrm{Al}_{2} \mathrm{O}_{3}$ powder mixture. Each equilibration experiment consisted initially equal masses of $\sim 250 \mathrm{mg}$ copper master alloy and slag.

\section{Equilibration time}

The required experimental time was determined with a preexperimental time series consisting of $1 \mathrm{~h}, 2 \mathrm{~h}, 4 \mathrm{~h}, 8 \mathrm{~h}$ and $16 \mathrm{~h}$ equilibration experiments. The equilibrium was approached from different directions using two slags: a pre-reacted ironsilicate slag $\left(\mathrm{Fe}_{2} \mathrm{O}_{3}-\mathrm{SiO}_{2}-20 \mathrm{wt} \% \mathrm{Al}_{2} \mathrm{O}_{3}\right.$ pellet was heated for $1 \mathrm{~h}$ at $\mathrm{N}_{2}$ atmosphere and $1100{ }^{\circ} \mathrm{C}$ ) and a powder mixture of $\mathrm{Fe}_{2} \mathrm{O}_{3}-\mathrm{SiO}_{2}-\mathrm{Al}_{2} \mathrm{O}_{3}$. Furthermore, two types of copper alloys (incl. $1 \mathrm{wt} \%$ of $\mathrm{Ag}, \mathrm{Au}, \mathrm{Pd}$ and $\mathrm{Pt}$ ) were employed: a powder mixture and the pre-smelted copper master alloy. Equal weights $(250 \mathrm{mg}$ ) of copper and slag were put in alumina crucible and equilibrated at $1300^{\circ} \mathrm{C}$ and $p O_{2}=10^{-7} \mathrm{~atm}$. Samples were analyzed with a Scanning Electron Microscope (SEM) LEO 1450 (Carl Zeiss Microscopy, Germany) equipped with an Oxford Instrument X-Max $50 \mathrm{~mm}^{2}+$ INCA Energy Dispersive X-ray Spectrometer (EDS, Oxford Instruments, UK) using acceleration voltage of $15 \mathrm{kV}$. Figure 1 presents the results for $\mathrm{Fe}, \mathrm{Si}$ and $\mathrm{Cu}$ in slag, as well as $\mathrm{Fe}$ and $\mathrm{Al}$ concentrations in discrete spinels.

As can be seen from Fig. 1, slag and Al-Fe spinel reached equilibrium in $8 \mathrm{~h}$. For shorter times $(1 \mathrm{~h}, 2 \mathrm{~h}$ and $4 \mathrm{~h})$ the compositions of slag and spinel were not entirely homogeneous, and thus produced higher standard deviations than in the completely equilibrated samples. The equilibrium time was also determined for the $\mathrm{Fe}_{2} \mathrm{O}_{3}-\mathrm{SiO}_{2}-\mathrm{Al}_{2} \mathrm{O}_{3}-\mathrm{CaO}$ slag and the results confirmed that $8 \mathrm{~h}$ was needed to reach equilibrium. However, the experimental time was set to $16 \mathrm{~h}$ to absolutely ensure equilibrium conditions in the final experiments at all conditions investigated. The experimental apparatus and critical steps for equilibration - drop-quenching experiments have been presented more detailed elsewhere [11, 19].

The oxygen partial pressure in the furnace was controlled with $\mathrm{CO}$ (purity $\geq 99.997 \%$, AGA-Linde) and $\mathrm{CO}_{2}$ (purity $\geq 99.9992 \%$, AGA-Linde) gases at the experimental temperature $\left(1300{ }^{\circ} \mathrm{C}\right)$ by mass-flow controllers (Aalborg DFC26, USA; accuracy $\pm 1 \%$ of full scale). The equilibrium reaction considered for gas atmosphere is

$\mathrm{CO}+1 / 2 \mathrm{O}_{2}=\mathrm{CO}_{2}$.

The calculated $\mathrm{CO}_{2} / \mathrm{CO}$ ratios for each oxygen partial pressure using $K$ value of 71,985.23 (HSC 6.12) are shown 

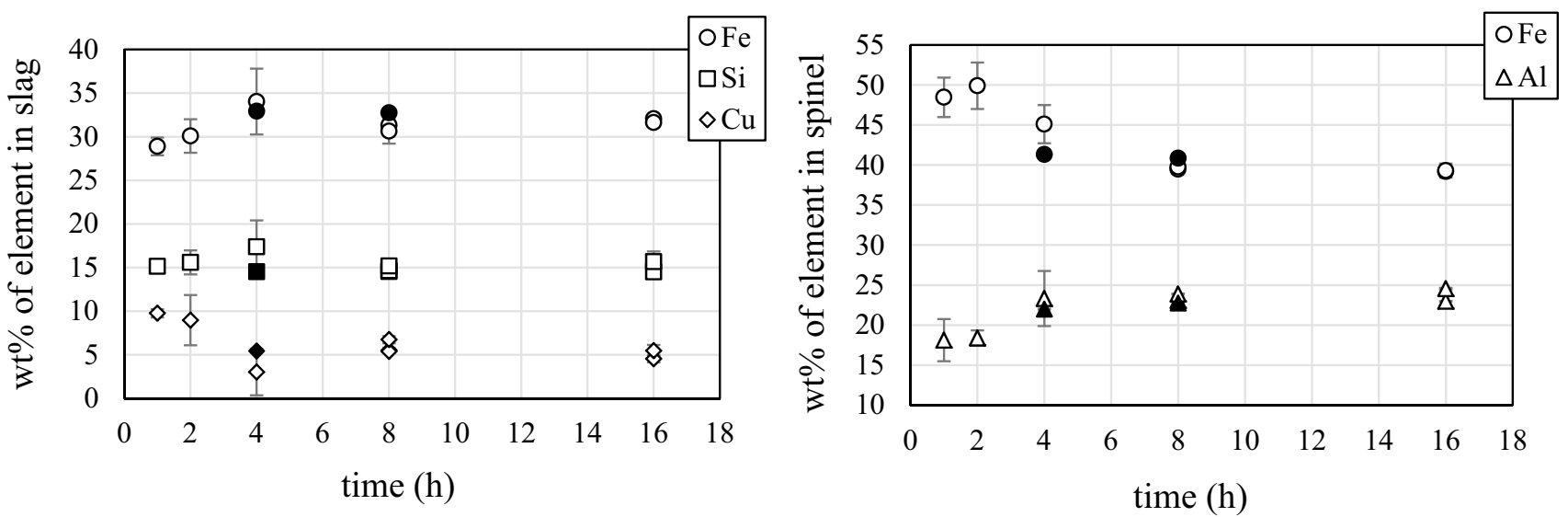

Fig. 1 Experimental results for equilibration time determination at $1300{ }^{\circ} \mathrm{C}$ and $p O_{2}=10^{-7}$ atm. Black marks refer to pre-reacted slag and white marks to slag powder mixture

in Table 1. The $\mathrm{CO}_{2} / \mathrm{CO}$ ratio was set for a total gas flow of $300 \mathrm{ml} / \mathrm{min}$ (STP) during the experiments.

\section{Sample analyses}

The samples were analyzed with a Cameca SX100 (Cameca, SAS, France) EPMA employing five wavelength dispersive spectrometers (WDS), and an Excite 193 nm ArF laser ablation system (Teledyne CETAC Technologies, Omaha, USA) with a $\mathrm{Nu}$ AttoM single collector ICP-MS (Nu Instruments Ltd., Wrexham, UK).

The EPMA analyses were performed for copper, slag and (solid) Al-Fe spinel phases. The acceleration voltage for EPMA analyses was $20 \mathrm{kV}$ and the electron beam current $40 \mathrm{nA}$. The beam diameter varied depending on the analyzed phase. For copper, the beam diameter was set to $100 \mu \mathrm{m}$, for spinel $1 \mu \mathrm{m}$ and for slag between 10 and $100 \mu \mathrm{m}$. The average elemental detection limits obtained are presented in Table 2. The detection limits were not sufficient to determine

Table 1 Calculated $\mathrm{CO}_{2} / \mathrm{CO}$ flow ratios at $1300{ }^{\circ} \mathrm{C}$

\begin{tabular}{lc}
\hline$p_{O_{2}}(\mathrm{~atm})$ & $\mathrm{CO}_{2} / \mathrm{CO}$ ratio \\
\hline $1 \times 10^{-5}$ & 227.6 \\
$1 \times 10^{-6}$ & 72.0 \\
$1 \times 10^{-7}$ & 22.8 \\
$1 \times 10^{-8}$ & 7.2 \\
$1 \times 10^{-9}$ & 2.3 \\
$1 \times 10^{-10}$ & 0.7 \\
\hline
\end{tabular}

the precious metal concentrations in slag and $\mathrm{Al}-\mathrm{Fe}$ spinels reliably.

The LA-ICP-MS analyses were performed for accurate and sensitive determination of precious metal concentrations in slags. Both slag types were investigated with $40 \mu \mathrm{m}$ and $110 \mu \mathrm{m}$ ablation spot sizes, and some of the $\mathrm{CaO}$-free slag samples were also analyzed with a spot size of $155 \mu \mathrm{m}$. The analysis parameters and standards used are presented in Table 3.

The analyses were conducted in time-resolved analysis (TRA) mode, with each analysis consisting of $20 \mathrm{~s}$ of background measurement prior to switching the laser on for 40-60 s of signal measurement. Baseline reduction and quantification of the trace element data was performed using the Glitter software package (GEMOC Laser ICPMS Total Trace Element Reduction; Macquarie University, Australia) [21]. The instrumental uncertainty of the LA-ICP-MS technique was $\pm 5-10 \%$ based on analyses of NIST 610 [22], BHVO-2G and BCR-2G [23] reference materials carried out during the analytical sessions.

The detection limits of LA-ICP-MS with $40 \mu \mathrm{m}$ spot size were not sufficiently low to detect gold, platinum and palladium in slags at experimental conditions $p \mathrm{O}_{2}<10^{-5}$ atm. The detection limits for $40 \mu \mathrm{m}$ spot were approximately 30 ppbw for $\mathrm{Ag}$ and $\mathrm{Pd}$, and 5 ppbw for $\mathrm{Pt}$ and Au. Eight of the samples, covering both slags and the entire $\mathrm{pO}_{2}$ range, were re-analyzed with larger laser spots (110 and $155 \mu \mathrm{m}$ ), which improved the accuracy and lowered the detection limits. The trace element concentrations of $\mathrm{Al}-\mathrm{Fe}$ spinels formed within the liquid slag domain

Table 2 Elemental detection limits of EPMA (ppmw)

\begin{tabular}{lllllllll}
\hline $\mathrm{O}$ & $\mathrm{Si}$ & $\mathrm{Cu}$ & $\mathrm{Al}$ & $\mathrm{Fe}$ & $\mathrm{Ag}$ & $\mathrm{Au}$ & $\mathrm{Pd}$ & $\mathrm{Pt}$ \\
\hline 1315 & 223 & 239 & 240 & 230 & 402 & 1753 & 401 & 1255 \\
\hline
\end{tabular}



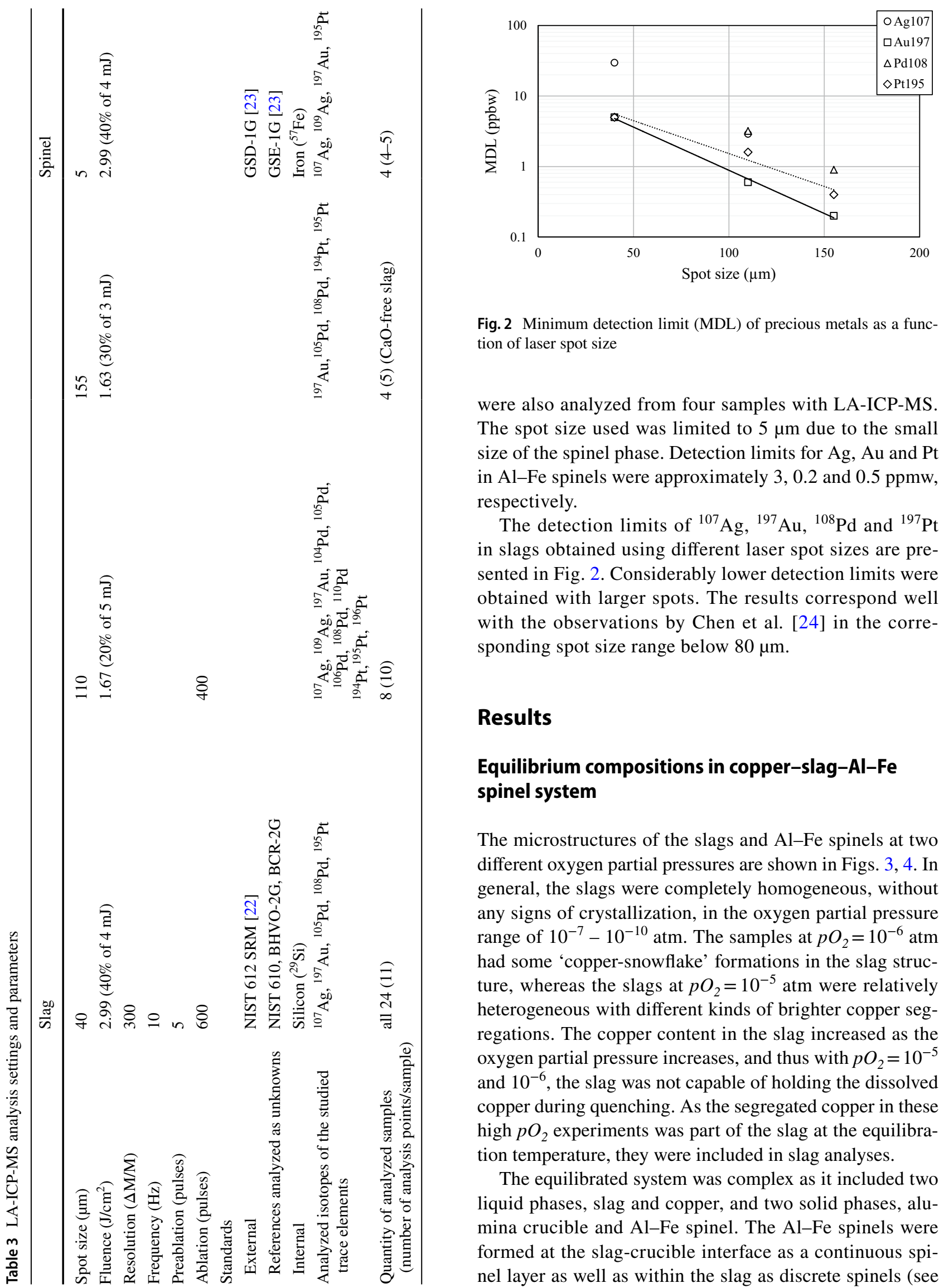

Fig. 2 Minimum detection limit (MDL) of precious metals as a function of laser spot size

were also analyzed from four samples with LA-ICP-MS. The spot size used was limited to $5 \mu \mathrm{m}$ due to the small size of the spinel phase. Detection limits for $\mathrm{Ag}, \mathrm{Au}$ and $\mathrm{Pt}$ in $\mathrm{Al}-\mathrm{Fe}$ spinels were approximately 3, 0.2 and $0.5 \mathrm{ppmw}$, respectively.

The detection limits of ${ }^{107} \mathrm{Ag},{ }^{197} \mathrm{Au},{ }^{108} \mathrm{Pd}$ and ${ }^{197} \mathrm{Pt}$ in slags obtained using different laser spot sizes are presented in Fig. 2. Considerably lower detection limits were obtained with larger spots. The results correspond well with the observations by Chen et al. [24] in the corresponding spot size range below $80 \mu \mathrm{m}$.

\section{Results}

\section{Equilibrium compositions in copper-slag-Al-Fe spinel system}

The microstructures of the slags and Al-Fe spinels at two different oxygen partial pressures are shown in Figs. 3, 4. In general, the slags were completely homogeneous, without any signs of crystallization, in the oxygen partial pressure range of $10^{-7}-10^{-10} \mathrm{~atm}$. The samples at $p O_{2}=10^{-6} \mathrm{~atm}$ had some 'copper-snowflake' formations in the slag structure, whereas the slags at $p O_{2}=10^{-5}$ atm were relatively heterogeneous with different kinds of brighter copper segregations. The copper content in the slag increased as the oxygen partial pressure increases, and thus with $p O_{2}=10^{-5}$ and $10^{-6}$, the slag was not capable of holding the dissolved copper during quenching. As the segregated copper in these high $\mathrm{pO}_{2}$ experiments was part of the slag at the equilibration temperature, they were included in slag analyses.

The equilibrated system was complex as it included two liquid phases, slag and copper, and two solid phases, alumina crucible and $\mathrm{Al}-\mathrm{Fe}$ spinel. The Al-Fe spinels were formed at the slag-crucible interface as a continuous spinel layer as well as within the slag as discrete spinels (see 
Fig. 3 BSE sample micrograph at $1300{ }^{\circ} \mathrm{C}$ and $10^{-9} \mathrm{~atm}$
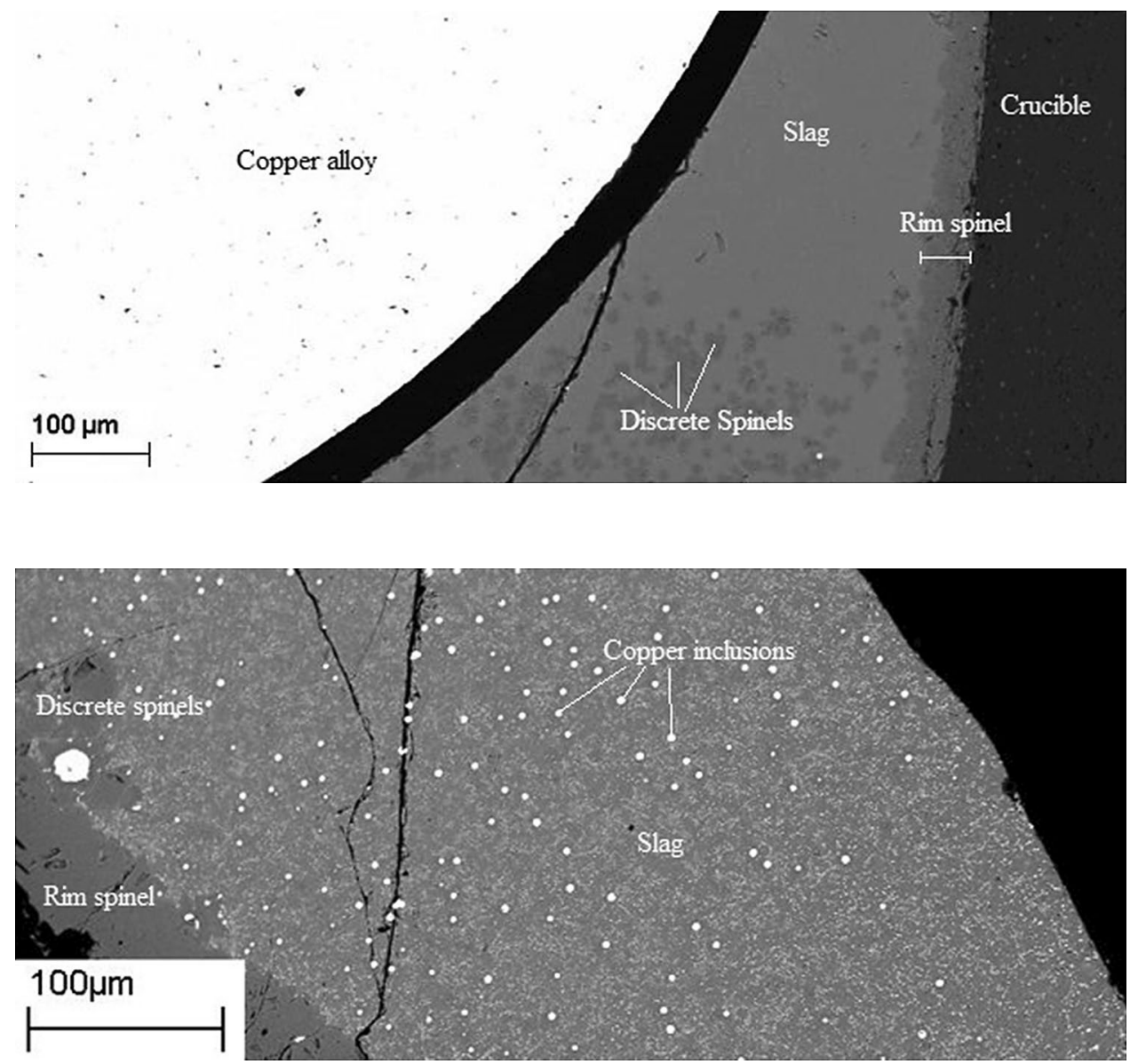

Fig. 4 BSE sample micrograph at $1300{ }^{\circ} \mathrm{C}$ and $10^{-5} \mathrm{~atm}$
Figs. 3, 4). Thus, the copper-slag system was in direct Al-Fe spinel saturation. The following sections present all the results separately for each phase in the system (excluding pure alumina crucible).

\section{Copper alloy}

Figure 5 presents the analysis results of copper and iron in the copper alloy phase. When the oxygen partial pressure increased, the copper concentration stayed constant and iron concentration decreased. The EPMA detection limit for iron was 230 ppmw, which explains the large standard deviations in the analyses of the lower oxygen partial pressure experiments. As expected, lime addition in slag did not have an impact on the copper phase composition.

The concentrations of precious metals in the copper alloy decrease somewhat as a function of decreasing oxygen partial pressure. Interestingly, as can be seen in Fig. 6, Au and Ag show similar trends between each other, likewise palladium and platinum concentrations. In the highest oxygen partial pressure(s), the volume of the copper alloy phase decreased somewhat as part of copper dissolved into the slag phase. Thus, the concentrations of precious metals, which highly favored copper, in every experimental condition, show small increase towards the higher oxygen partial pressures.

\section{Slag}

The composition of the slags can be defined by $\mathrm{Fe} / \mathrm{SiO}_{2}$ ratio, $\mathrm{Cu}, \mathrm{Al}_{2} \mathrm{O}_{3}$ and $\mathrm{CaO}$ concentrations in slag. The concentration of aluminum was constant around 9-10 wt\% in slag (17-20 wt $\%$ as $\mathrm{Al}_{2} \mathrm{O}_{3}$ ). The concentration of calcium in lime-containing slags was between 3.3-4.3 wt\% (4.6-6 wt $\%$ as $\mathrm{CaO}$ ). Figure 7 shows the obtained $\mathrm{Fe} / \mathrm{SiO}_{2}$ ratios as well as the copper loss in the slag as a function of oxygen partial pressure.

The iron-to-silica ratio increases somewhat with the decreasing oxygen partial pressure. As the $\mathrm{SiO}_{2}$ level in slag stayed relatively constant at 30-33 wt\% (except at the highest $\mathrm{pO}_{2}=10^{-5}$ atm, where $\mathrm{SiO}_{2}$ decreased to $\sim 25 \mathrm{wt} \%$ ), iron behavior in slag was mostly responsible for the changes in the $\mathrm{Fe} / \mathrm{SiO}_{2}$ ratio. The behavior of iron was further related to the spinels, where iron concentration also changed along with the oxygen partial pressure. The copper loss in slags was highly dependent on the oxygen partial pressure and 

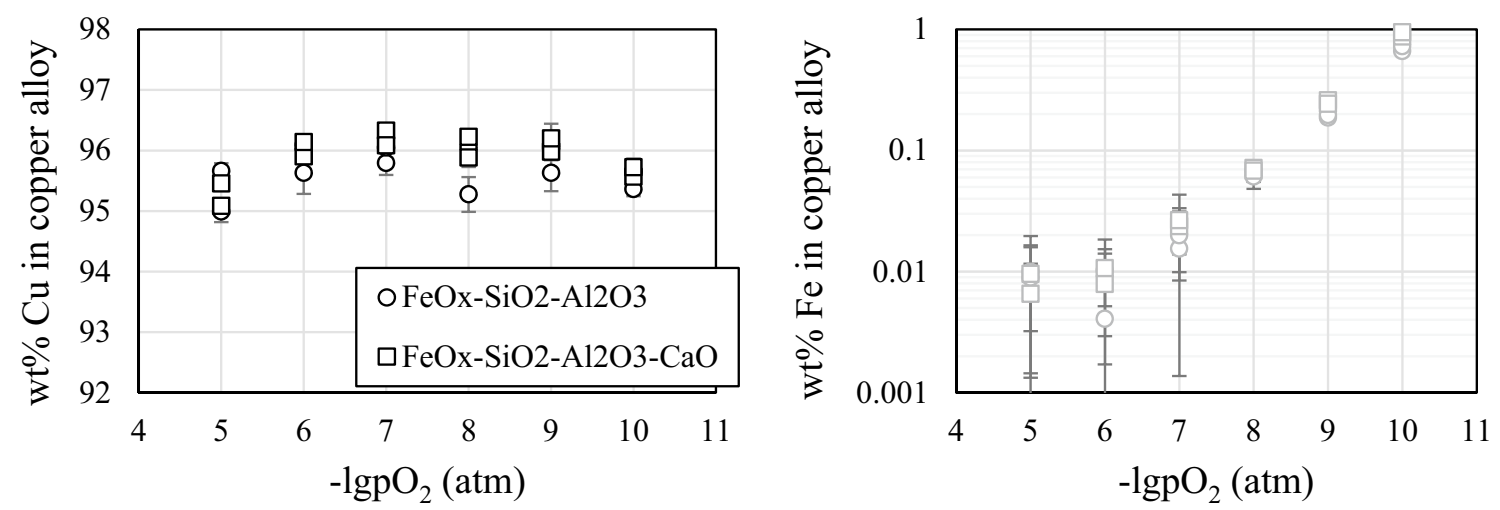

Fig. 5 Concentrations of copper (left-side) and iron (right-side) in the copper alloy as a function of oxygen partial pressure at $1300{ }^{\circ} \mathrm{C}$. White circle indicates to $\mathrm{CaO}$-free slag, whereas white square indicates to $\mathrm{CaO}$-containing slag
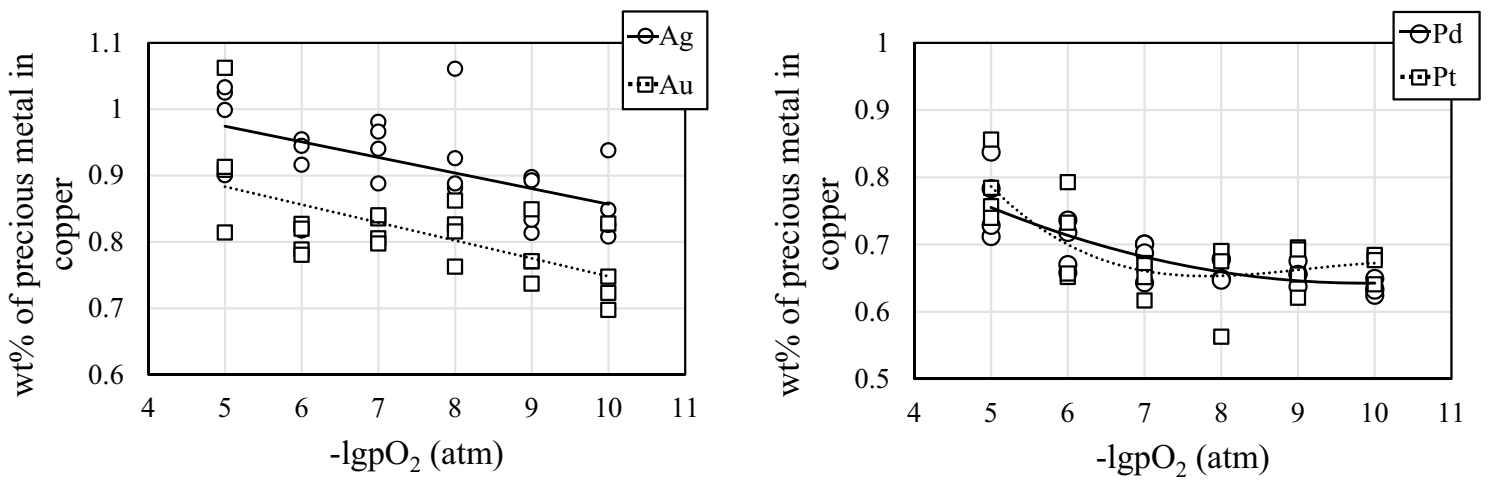

Fig. 6 Precious metal concentrations in copper alloy phase as a function of oxygen partial pressure at $1300{ }^{\circ} \mathrm{C}$
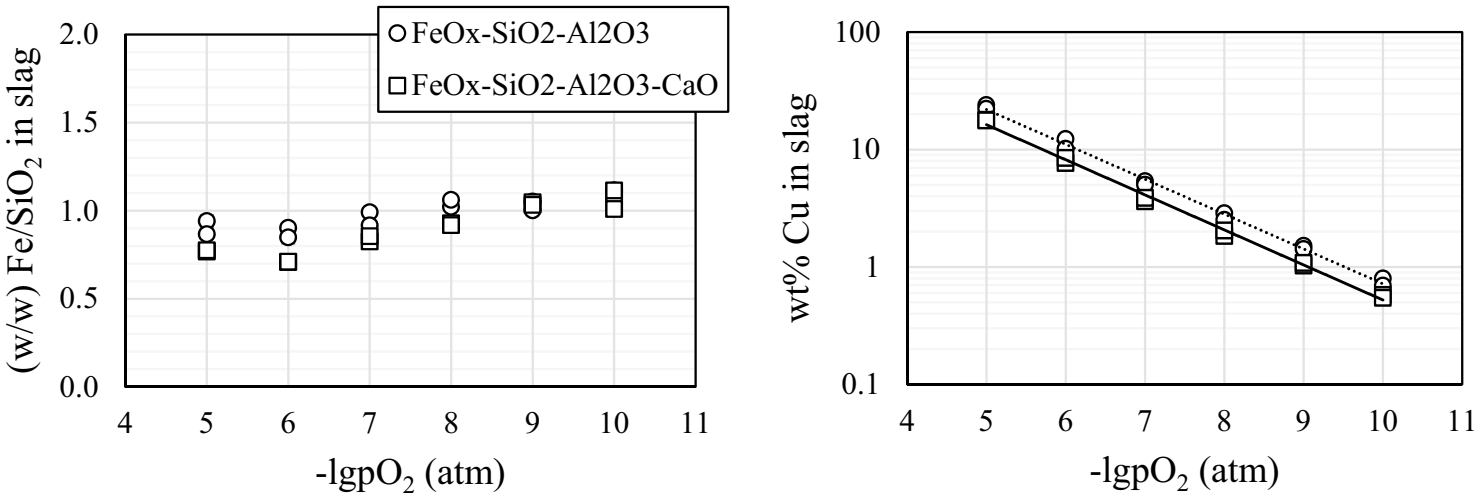

Fig. $7 \mathrm{Fe} / \mathrm{SiO}_{2}$ ratio and copper concentration in slags as a function of oxygen partial pressure at $1300{ }^{\circ} \mathrm{C}$. White circle indicates to $\mathrm{CaO}$-free slag, whereas white square indicates to $\mathrm{CaO}$-containing slag

the slag composition, as shown in Fig. 7. Similar copper solubilities in slags were determined by Avarmaa et al. [10], Nishijima and Yamaguchi [25] and Hidayat et al. [15]. The copper loss increased drastically with the increased oxygen pressure, approximately with a slope of $0.28-0.29$ indicating to oxide form of $\mathrm{CuO}_{0.5}\left(\mathrm{Cu}^{+}\right)$in the slag. The copper loss in the slag was decreased by approximately $20-30 \%$ with an addition of $5 \mathrm{wt} \% \mathrm{CaO}$. This positive influence of lime has also been observed in other studies [10, 26, 27]. 
The silver concentration in slags was reliably determined from all the samples employing the LA-ICP-MS technique, even with the small analysis spot of $40 \mu \mathrm{m}$ (Fig. 8). Silver concentration in slag was clearly dependent on the oxygen partial pressure and the slag composition. Lime addition decreased its concentration in slag. Other precious metals ( $\mathrm{Au}, \mathrm{Pt}$ and $\mathrm{Pd}$ ) were not detected in slags with the smallest spot size employed, except gold at the highest oxygen partial pressure [19].

Eight samples were re-analyzed with a larger laser spot $(110 \mu \mathrm{m})$, and 10 analysis points were taken from each sample. Furthermore, four of the samples (CaO-free slag) were re-checked with a $155 \mu \mathrm{m}$ spot size. Table 4 presents the analysis results, the calculated averages with the standard deviations, and shows in how many analysis points the metal was observed relative to the total number of analysis points. The detection limits are marked in brackets () for each element and sample. The average values for platinum were calculated from the determined concentrations excluding the zero-results, using isotopes ${ }^{194} \mathrm{Pt}$ and ${ }^{195} \mathrm{Pt}$. Their natural abundance is close to each other, and thus they provide similar minimum detections limits. The standard deviations were calculated only if the trace element was detected in nearly every analysis point taken.

Gold was detected reliably in the samples at the highest oxygen partial pressure $\mathrm{pO}_{2}=10^{-5}$ atm. Reliably in this case means detected in every analysis point taken, clearly above the detection limit and with clear signals in the TRAspectrums. Moreover, the detected concentrations were the same with all spot sizes employed. Figure 9 (left side) presents time-resolved analysis (TRA) spectrums for gold in $\mathrm{SiO}_{2}-\mathrm{FeO}_{\mathrm{x}}-\mathrm{Al}_{2} \mathrm{O}_{3}$ and $\mathrm{SiO}_{2}-\mathrm{FeO}_{\mathrm{x}}-\mathrm{Al}_{2} \mathrm{O}_{3}-\mathrm{CaO}$ slags. The analysis started at approximately $24 \mathrm{~s}$. Both slags gave clear signals: $\mathrm{CaO}$-free slag with higher $\mathrm{Au}$ concentration generated a larger signal (cps) than the $\mathrm{CaO}$-containing slag. For the rest of the samples at $p O_{2}=10^{-6}-10^{-10}$ atm, gold concentrations were near or below detection limits and the TRA spectrums did not show signals distinguishable from the background (see Fig. 9 right side). Platinum concentrations were not explicitly above the detection limit in any sample (spectrums as in Fig. 9 right side), except with $155 \mu \mathrm{m}$ spot size at $10^{-5} \mathrm{~atm}$.

The palladium concentration in slags was measured with isotopes ${ }^{104} \mathrm{Pd},{ }^{105} \mathrm{Pd},{ }^{106} \mathrm{Pd},{ }^{108} \mathrm{Pd}$ and ${ }^{110} \mathrm{Pd}$. However, because of significant interference of palladium isotope ${ }^{105} \mathrm{Pd}$ with ${ }^{40} \mathrm{Ar}^{65} \mathrm{Cu}^{+}$, this isotope provided false results with too high concentrations and cannot be used for determining palladium concentration in slags with high concentrations of copper. Moreover, ${ }^{106} \mathrm{Pd},{ }^{108} \mathrm{Pd}$ and ${ }^{110} \mathrm{Pd}$ isotopes have isobaric interferences when using NIST 612 SRM as the primary standard material from Cd-isotopes and additionally ${ }^{94} \mathrm{Zr}^{16} \mathrm{O}^{+}$for ${ }^{110} \mathrm{Pd}$ [28]. In this case, the calculated $\mathrm{Pd}$ concentrations were lower than the true concentrations.

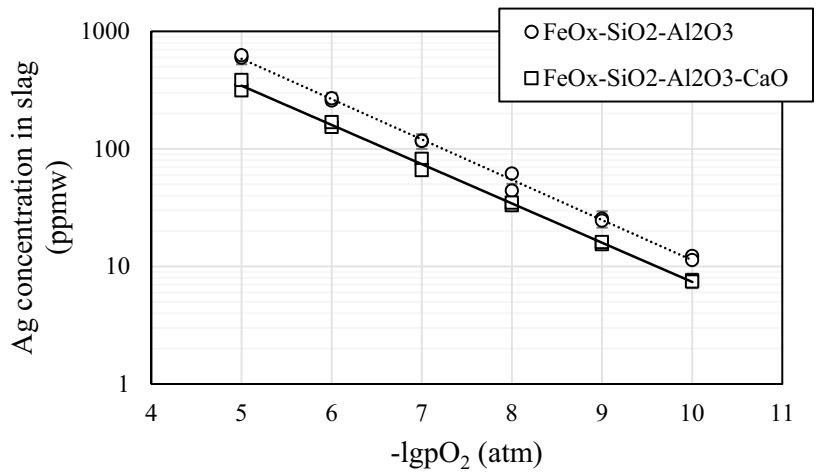

Fig. 8 Silver concentration $\left({ }^{107} \mathrm{Ag}\right)$ in slag as a function of oxygen partial pressure at $1300{ }^{\circ} \mathrm{C}$. White circle indicates to $\mathrm{CaO}$-free slag and white square to $\mathrm{CaO}$-containing slag

Isotope ${ }^{104} \mathrm{Pd}$ has fewer interferences, and would seem ideal to provide reliable results, but the ${ }^{104} \mathrm{Pd}$ isotope makes up only $11 \%$ of Pd abundance, producing results mainly below the detection limit. For these reasons, corrected palladium concentrations were calculated for isotopes ${ }^{106} \mathrm{Pd}$ and ${ }^{108} \mathrm{Pd}$, which should provide the most accurate results. The correction formula can be presented as:

$\left(C_{x}\right)_{\mathrm{samp}}=\frac{\left[I_{x} / I_{\mathrm{Is}}\right]_{\mathrm{samp}} *\left(C_{\mathrm{Is}}\right)_{\mathrm{samp}} *\left(C_{x}\right)_{\mathrm{std}}}{\left[I_{x} / I_{\mathrm{Is}}\right]_{\mathrm{std}} *\left(C_{\mathrm{Is}}\right)_{\mathrm{std}}}$,

where $I$ (Intensity) refers to background-subtracted mean counts per second (cps), $C$ to concentration (ppmw), $x$ to isotope under investigation $\left({ }^{106} \mathrm{Pd}\right.$ or ${ }^{108} \mathrm{Pd}$ ) and Is to internal standard $\left({ }^{29} \mathrm{Si}\right)$. Moreover, subscripts samp and std refer to values determined for the unknown sample and external NIST612 standard, respectively. Corrections were calculated employing the interference-free ${ }^{111} \mathrm{Cd}$ isotope to obtain true $I_{x}$ values of ${ }^{106} \mathrm{Pd}$ and ${ }^{108} \mathrm{Pd}$, respectively:

$I_{x}=I_{108_{\mathrm{Pd}}}-\left(I_{111_{\mathrm{Cd}}} * \mathrm{NA}\left({ }^{108} \mathrm{Cd} /{ }^{111} \mathrm{Cd}\right)\right.$,

$I_{x}=I_{106_{\mathrm{Pd}}}-\left(I_{111_{\mathrm{Cd}}} * \mathrm{NA}\left({ }^{106} C d /{ }^{111} C d\right)\right.$,

where NA denotes natural abundance in at- $\%$. These formulas corrected the isobaric interferences of ${ }^{106} \mathrm{Cd}$ on ${ }^{106} \mathrm{Pd}$ and ${ }^{108} \mathrm{Cd}$ on ${ }^{108} \mathrm{Pd}$ from NIST612 standard, which were impossible to separate with the low mass resolution settings required for sensitive laser ablation analyses. This type of correction is typical in geology [29] but is now applied for the first time in the analysis of metallurgical slags. The corrected results are presented in Table 5 .

The results for the highest oxygen partial pressure were reliable for both slags. However, the results for the rest of the samples with spot size $110 \mu \mathrm{m}$ were most likely somewhat 
Table 4 Analysis results for Au and Pt concentrations in slags with larger laser spot sizes

\begin{tabular}{|c|c|c|c|c|c|c|c|c|c|c|}
\hline \multirow{2}{*}{\multicolumn{2}{|c|}{$\frac{\text { Analysis spot size }}{\text { Sample }}$}} & \multirow[b]{2}{*}{$\begin{array}{l}-\operatorname{lgpO} O_{2} \\
(\mathrm{~atm})\end{array}$} & \multicolumn{2}{|l|}{$110 \mu \mathrm{m}$} & \multicolumn{2}{|l|}{$155 \mu \mathrm{m}$} & \multicolumn{2}{|l|}{$110 \mu \mathrm{m}$} & \multicolumn{2}{|l|}{$155 \mu \mathrm{m}$} \\
\hline & & & $\mathrm{Pt}$ (ppbw) & $\begin{array}{l}\text { Observed/ } \\
\text { total } \\
\text { analyses } \\
\text { (MDL) }\end{array}$ & $\mathrm{Pt}$ (ppbw) & $\begin{array}{l}\text { Observed/ } \\
\text { total } \\
\text { analyses } \\
\text { (MDL) }\end{array}$ & $\mathrm{Au}$ (ppbw) & $\begin{array}{l}\text { Observed/ } \\
\text { total } \\
\text { analyses } \\
\text { (MDL) }\end{array}$ & $\mathrm{Au}$ (ppbw) & $\begin{array}{l}\text { Observed/total } \\
\text { analyses (MDL) }\end{array}$ \\
\hline \multirow{4}{*}{$\begin{array}{l}\mathrm{CaO} \text {-free } \\
\text { slag }\end{array}$} & F19 & 5 & 5.2 & $11 / 20(1.8)$ & $2.39 \pm 0.79$ & $5 / 5(0.4)$ & $43.2 \pm 9.5$ & $10 / 10(0.6)$ & $48.38 \pm 5.15$ & $5 / 5(0.2)$ \\
\hline & F25 & 6 & 3.2 & $6 / 20(1.8)$ & 0.67 & $2 / 5(0.5)$ & $3.5 \pm 1.8$ & $10 / 10(0.5)$ & $1.2 \pm 0.49$ & $5 / 5(0.3)$ \\
\hline & F26 & 8 & 2.9 & $6 / 14(1.8)$ & 0.56 & $1 / 5(0.4)$ & $2.7 \pm 1.7$ & $5 / 6(0.6)$ & $0.68 \pm 0.25$ & $5 / 5(0.2)$ \\
\hline & F18 & 10 & 2.2 & $2 / 20(1.4)$ & 3.34 & $3 / 5(0.4)$ & $2.0 \pm 0.8$ & $8 / 10(0.4)$ & $2.24 \pm 1.86$ & $4 / 5(0.2)$ \\
\hline \multirow{4}{*}{$\begin{array}{l}\mathrm{CaO}-\text { con- } \\
\text { taining }\end{array}$} & $\mathrm{F} 15$ & 5 & 3.7 & $9 / 20(1.6)$ & & & $24.7 \pm 3.6$ & $10 / 10(0.5)$ & & \\
\hline & F16 & 6 & 5.7 & $8 / 20(3.4)$ & & & 1.4 & $4 / 10(1)$ & & \\
\hline & $\mathrm{F} 14$ & 8 & 4.6 & $6 / 18(1.6)$ & & & 3.3 & $3 / 9(0.7)$ & & \\
\hline & F12 & 10 & 2.9 & $13 / 20(1.3)$ & & & 0.9 & $4 / 10(0.6)$ & & \\
\hline
\end{tabular}
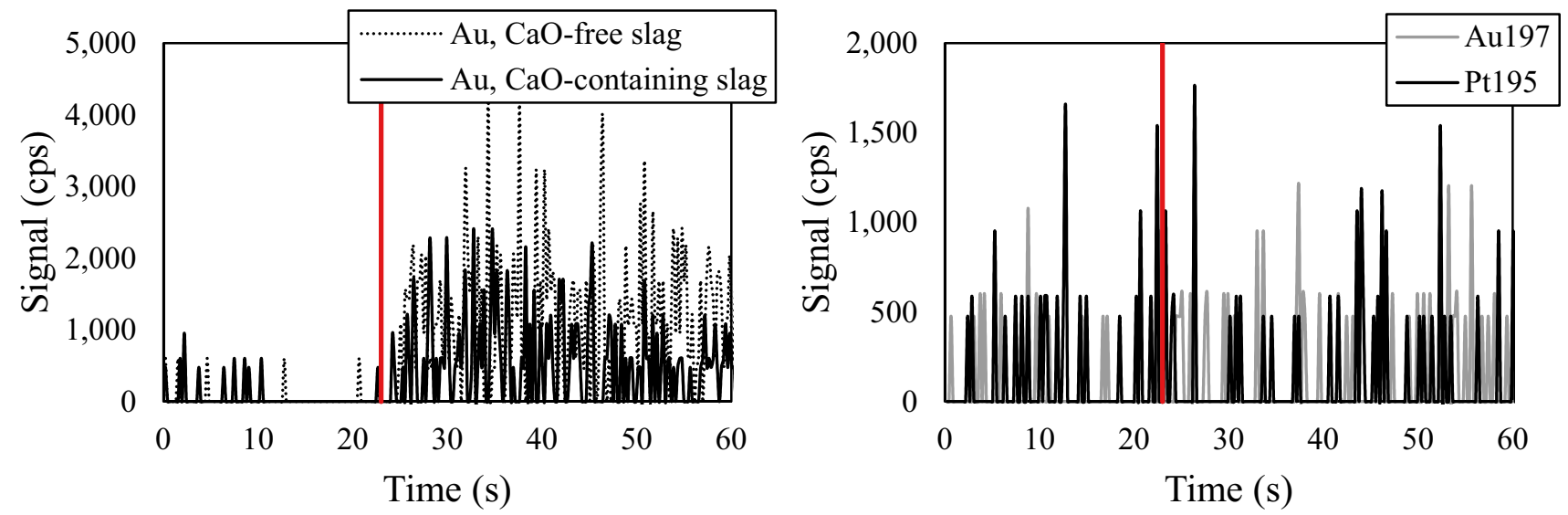

Fig. 9 TRA-spectrums for ${ }^{197} \mathrm{Au}$ in both slags at $p O_{2}=10^{-5}$ atm (left side) and for ${ }^{197} \mathrm{Au}$ and ${ }^{195} \mathrm{Pt}$ in $\mathrm{CaO}$-free slag at $p O_{2}=10^{-6}$ atm with spot size $110 \mu \mathrm{m}$ (right side). Red lines indicate the times when laser was switched on (color figure online)

too high, and the results with spot size $155 \mu \mathrm{m}$ closer to the true concentrations.

Figure 10 presents ${ }^{108} \mathrm{Pd}$ spectrums at the oxygen partial pressure of $10^{-5} \mathrm{~atm}$ with two spot sizes (110 and $\left.155 \mu \mathrm{m}\right)$. The spectrums show reasonably clear signals with both spot sizes, but especially with $155 \mu \mathrm{m}$ (see the point where the sample measurement starts). Also, the sample F25 (CaOfree at $10^{-6} \mathrm{~atm}$ ) showed a clear signal when analyzed with the largest spot size. In the rest of the samples, the analysis signals were not distinguishable from the background.

\section{Spinel}

The main elements in the spinel phase were iron, aluminum and oxygen. In addition, low concentrations of copper (0.03-3.5 wt\%), silicon (0.03-0.09 wt\%) and calcium in $\mathrm{CaO}$-containing slag $(0.03-0.07 \mathrm{wt} \%)$ were detected. Figure 11 shows the obtained iron and aluminum concentrations, as well as copper concentration in spinel with their standard deviations, as a function of oxygen partial pressure. The EPMA measurements were performed from the discrete spinels in the bulk slag.

The composition of spinels changed as the oxygen partial pressure changed; iron concentration decreased whereas aluminum concentration increased with a decreasing oxygen partial pressure. In addition, as the oxygen pressure increased, the spinel phase dissolved increasingly more copper. The general spinel structure can be presented as $\mathrm{A}^{2+} \mathrm{B}_{2}{ }^{3+} \mathrm{O}_{4}$, which in this case is $\left(\mathrm{Fe}^{2+}, \mathrm{Cu}^{2+}\right)$ $\left(\mathrm{Fe}^{3+}, \mathrm{Al}^{3+}\right)_{2} \mathrm{O}_{4}[30]$. As the oxygen pressure increased, so did the relative proportions of $\mathrm{Fe}^{3+}$ and $\mathrm{Cu}^{2+}$, while $\mathrm{Al}^{3+}$ and $\mathrm{Fe}^{2+}$ decreased.

Precious metals in spinels were checked from four samples using LA-ICP-MS technique. These samples were F12, F16, F19 and F25. According to the laser TRA-spectrums (cps) and calculated detection limits (MDL), no precious 


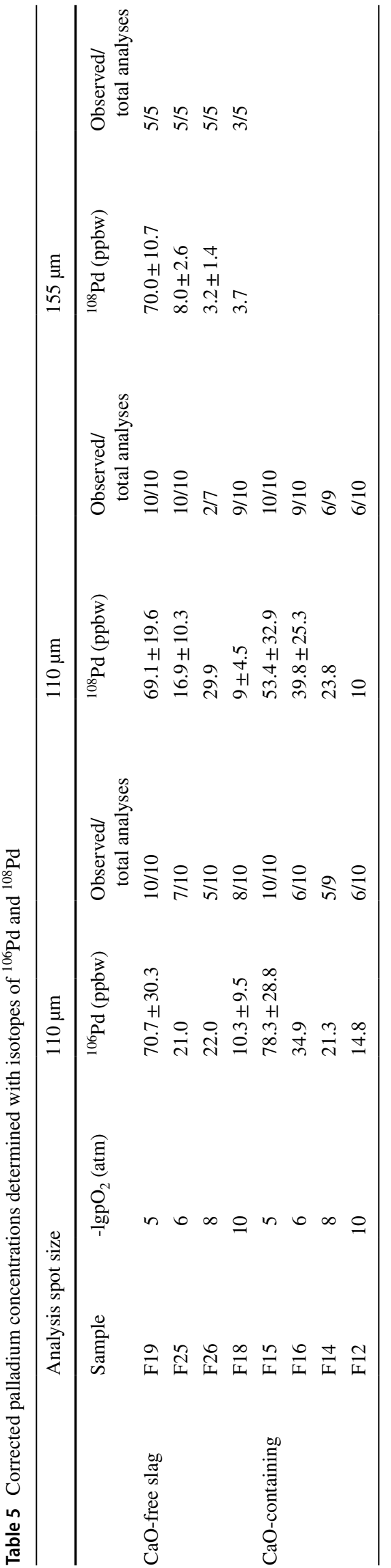

metals ( $\mathrm{Au}, \mathrm{Ag}, \mathrm{Pd}$ and $\mathrm{Pt}$ ) were detected in the spinels. The adopted spot size was very small $(5 \mu \mathrm{m})$ due to the small size of the spinel phase, and thus, the detection limits were quite high. For silver, gold and platinum, the concentrations in spinel phase were less than 3, 0.2 and 0.5 ppmw, respectively (the detection limits of LA-ICP-MS for these elements). Palladium concentration has not been determined in the external standard GSE-1G, and thus no detection limits or concentration values for this metal were obtained from the samples. However, based on the TRA-spectrums, there was no palladium dissolved in the spinel. The detection limit for Pd can be estimated to be in the same order of magnitude as for $\mathrm{Au}$ and $\mathrm{Pt}$.

\section{Discussion}

When examining the minor/trace element behavior in copper smelting, one of the most important parameters to be defined is the distribution coefficient. In general, the distribution equilibria of minor element $\mathrm{M}$ between copper metal and slag can be presented with the following equation:

$L^{C u / s}[M]=\frac{[\mathrm{wt} \% \mathrm{M}]_{\text {in copper }}}{(\mathrm{wt} \% \mathrm{M})_{\text {in slag }}}$,

where, in this study, []-brackets refer to copper alloy phase and ()-brackets to slag phase. This parameter is independent on the size of the system i.e. amounts of the phases and minor elements (following Henry's law). Thus, the determined coefficients are compatible with industrial secondary copper smelting operating at corresponding conditions with high-alumina slags. Here, the distribution coefficients were determined from the EPMA and LA-ICP-MS analyses for the alloy and slag, respectively. The 'zero-results' from LA-ICP-MS were not included in the calculations of average values. The uncertainties for the distribution coefficients were calculated similarly as in our previous papers [10, 31].

In general, the distribution reaction for minor element $\mathrm{M}$ between metal and slag can be presented with the following equation:

$[\mathrm{M}]+\mathrm{n} / 2 \mathrm{O}_{2}(\mathrm{~g})=\left(\mathrm{MO}_{\mathrm{n}}\right)$.

Using the equilibrium constant equation for reaction (5), the thermodynamic interpretation for the distribution coefficient can be further modified and rewritten in logarithmic form as:

$\lg L^{C u / s}[M]=-n / 2 \operatorname{lgp} O_{2}+\lg C$

where the constant $C$ includes the activity coefficients $(\gamma)$, the equilibrium constant $(K)$, and the total number of (cationic) moles $(n)$ in slag and copper. This thermodynamic 

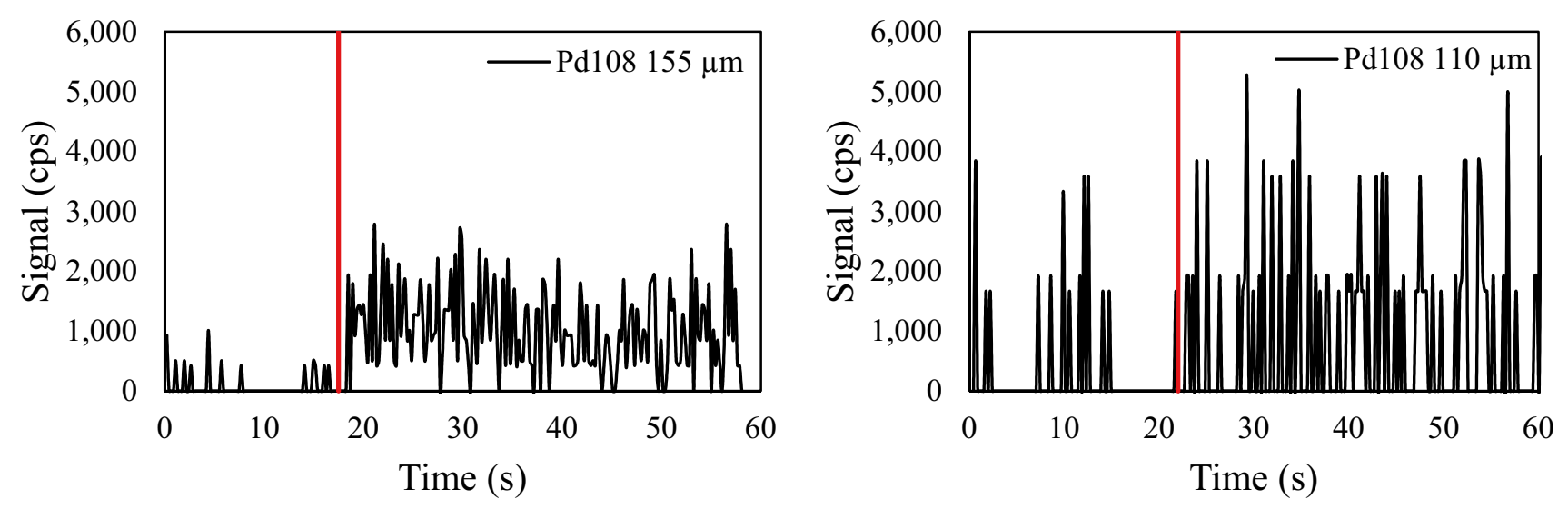

Fig. $10{ }^{108} \mathrm{Pd}$ spectrums in oxygen partial pressures of $10^{-5}$ atm with analysis spots of $155 \mu \mathrm{m}$ (left side) and $110 \mu \mathrm{m}$ (right side). Red lines indicate the times when laser was switched on (color figure online)
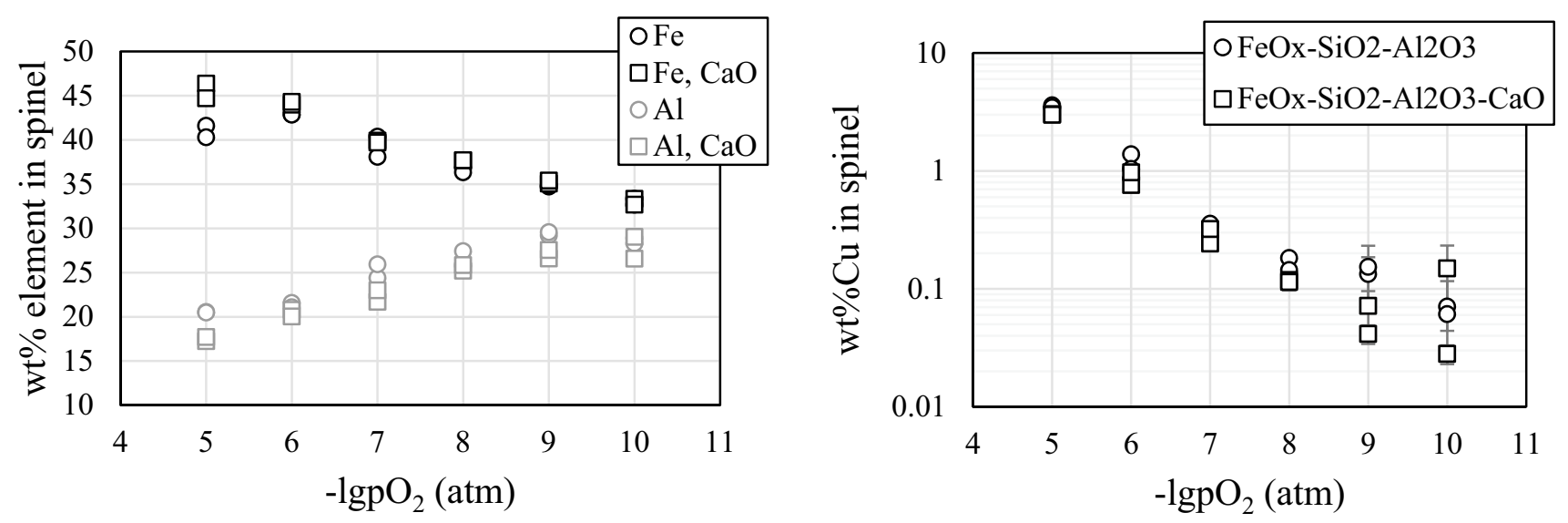

Fig. 11 Iron and aluminum concentrations in spinel (left-side), and copper in spinel (right-side) as a function of oxygen partial pressure

approach can be applied for determining the oxidation state of the minor element in the slag. The obtained distribution coefficients for all precious metals were collected in Fig. 12.

The distribution coefficient of silver, with uncertainties, as a function of oxygen partial pressure is presented in Fig. 12a. The (logarithmic) distribution coefficients for both slags increase linearly with decreasing oxygen partial pressure. The slope of the plot is approximately $1 / 3$, which suggests a silver oxide dissolution form of $\mathrm{Ag}_{3} \mathrm{O}_{2}$ (monocationic form $\mathrm{AgO}_{2 / 3}$ ). The distribution coefficient of silver was approximately doubled with the addition of $5 \mathrm{wt} \% \mathrm{CaO}$.

Most previous studies for a different type of slags have suggested dissolution as $\mathrm{Ag}^{+}$ions $\left(\mathrm{AgO}_{0.5}\right)$ [26, 32-34]. In general, the distribution coefficient of silver in our study for alumina-containing iron-silicate slag was lower than in the study by Takeda and Roghani [26] for all investigated slags. In addition, Hidayat's [15] distribution results between copper and silica-saturated iron silicate slag (at $1250{ }^{\circ} \mathrm{C}$ and $p O_{2}=10^{-7}-10^{-9} \mathrm{~atm}$ ) were somewhat higher than our results. On the other hand, $L^{C u / s}$ results in copperslag-tridymite system $\left(1300^{\circ} \mathrm{C}, 10^{-4}-10^{-8} \mathrm{~atm}\right)$ by Sukhomlinov and Taskinen [35] were very close to our results with $\mathrm{CaO}$-free slag. Moreover, the results by Chen et al. [24] in the matte-copper-slag-tridymite system (at $1200{ }^{\circ} \mathrm{C}$ and matte grade of $55-80 \mathrm{wt} \% \mathrm{Cu}$ ) were in the same range $\left(L^{\mathrm{Cu} / \mathrm{s}}[\mathrm{Ag}]=140-520\right)$ as ours.

For gold, platinum and palladium, the distribution coefficients were calculated using the results obtained with a spot size of $110 \mu \mathrm{m}$ for eight samples and $155 \mu \mathrm{m}$ for four samples. The distribution coefficient of gold as a function of oxygen partial pressure is presented in Fig. 12b. The standard deviations $( \pm \sigma)$ were included only for the reliable result points at higher oxygen pressures. At the highest oxygen partial pressure, the distribution coefficients of gold were $2.5 \times 10^{5}$ and $4 \times 10^{5}$ for $\mathrm{CaO}$-free and $\mathrm{CaO}$-containing slags, respectively. The slopes with spot size $110 \mu \mathrm{m}$ between $10^{-5}$ and $10^{-6}$ atm are around 1 for both slags, referring to $\mathrm{Au}^{4+}$ $\left(\mathrm{AuO}_{2}\right)$ as the dissolving species. However, for spot size 

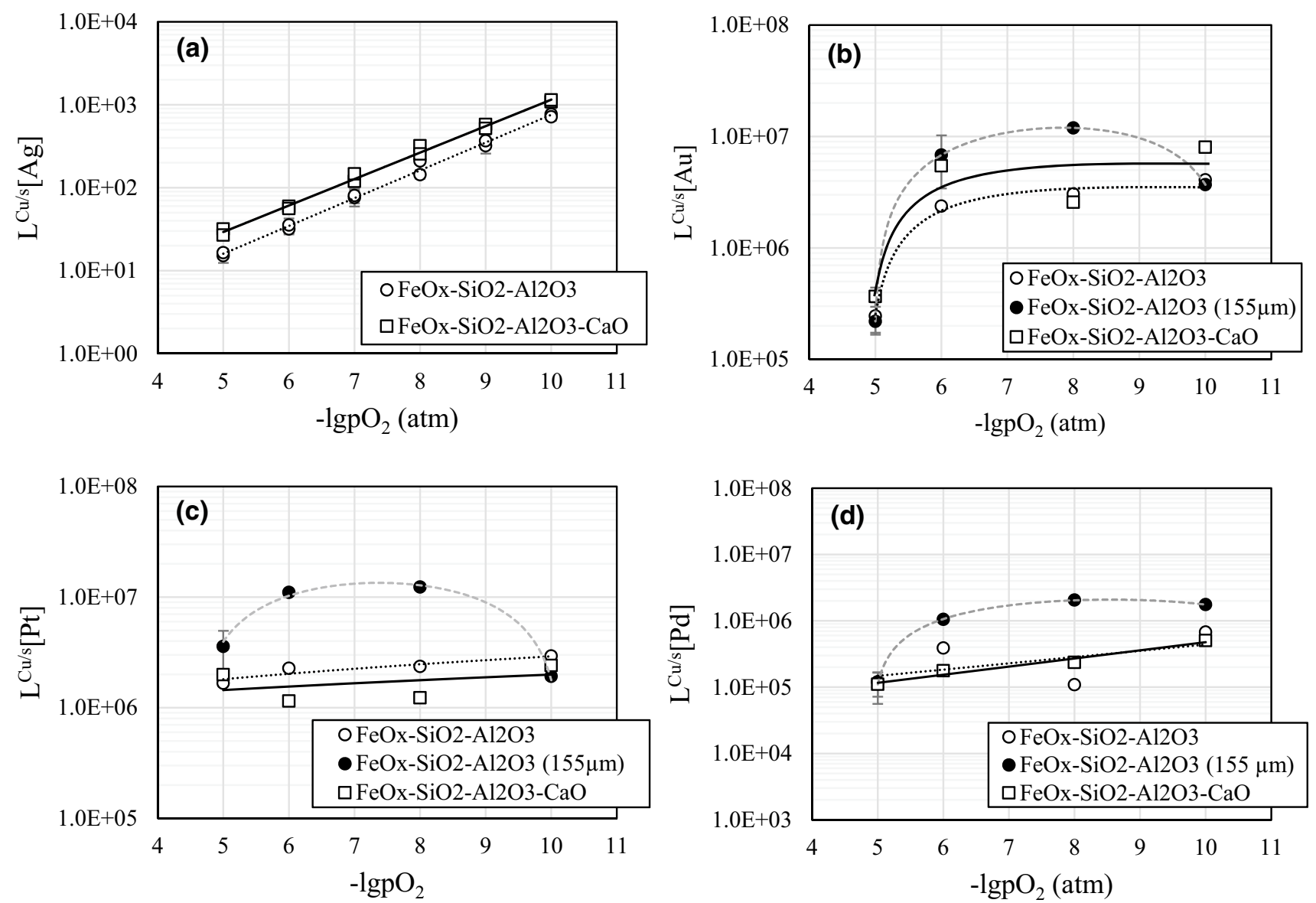

Fig. 12 Distribution coefficients of silver, gold, platinum and palladium between copper and slag as a function of oxygen partial pressure at $1300{ }^{\circ} \mathrm{C}$. The grey dashed trend lines indicate to the big spot size

$(155 \mu \mathrm{m})$ results for the $\mathrm{CaO}$-free slag, the black dotted trend lines to the smaller spot size $(110 \mu \mathrm{m})$ results for the $\mathrm{CaO}$-free slag and the black trend lines to $\mathrm{CaO}$-containing slag results $(110 \mu \mathrm{m}$ spot size $)$

$155 \mu \mathrm{m}$ slope is 1.87 . In lower oxygen partial pressures, the distribution coefficients increased above $10^{6}$ and close to $10^{7}$. Lime addition seemed to improve the gold recovery into metallic copper.

In general, most of the previous experimental studies [3639] have shown much higher gold concentrations in iron-silicate slags. One reason for this may be the mechanical separation of phases followed by bulk chemical analysis, which may lead to entrained copper droplets within the analyzed slag. Obviously, it is also dependent on the initial concentration of gold in the system. In recent studies, gold distribution coefficients between copper and slag in copper-silica-saturated iron-silicate slag system $\left(1300^{\circ} \mathrm{C}, p O_{2}=10^{-4}\right.$ $\left.-10^{-8} \mathrm{~atm}\right)$ were measured as $10^{5.5}-10^{7}[35]$ and in mattecopper-slag-tridymite system $\left(1200{ }^{\circ} \mathrm{C}\right)$ between $10^{5.3}$ and $10^{6}$ [24]. These are in excellent agreement with our results.

Distribution coefficients of platinum between copper and slag obtained with the laser spot sizes of 110 and $155 \mu \mathrm{m}$ are shown in Fig. 12c. The presented platinum distribution coefficients with spot size of $110 \mu \mathrm{m}$ represent lower

estimates only, as platinum was not detected in most of the analysis points in slags. Only with a spot size of $155 \mu \mathrm{m}$ at $p O_{2}=10^{-5}$ atm the results for platinum can be considered well quantified. Previous experimental studies on the platinum distribution coefficients $\left(L^{\mathrm{Cu} / \mathrm{s}}\right)$ measured much lower values of $10^{2}-10^{3}[25,40]$. Moreover, studies on platinum solubilities or concentrations in different types of slags suggest values higher in every case, e.g. 3-7 ppmw [18], 20-800 ppmw [41] and 10-100 ppmw [42], than those measured in the present study.

The distribution coefficients of palladium for both studied slags as a function of oxygen partial pressure are presented in Fig. 12d. For the slags, averages of the corrected palladium concentrations $\left({ }^{106} \mathrm{Pd}\right.$ and $\left.{ }^{108} \mathrm{Pd}\right)$ were used. Palladium distribution coefficients increased from approximately $10^{5}$ to $10^{6}$ as the oxygen partial pressure decreased. Results at $10^{-5}$ atm can be considered quantified, whereas at lower $\mathrm{pO}_{2}$ the distribution coefficients were minimum values, especially for the results with $110 \mu \mathrm{m}$ spot size. The determined distribution coefficients were clearly higher than in 

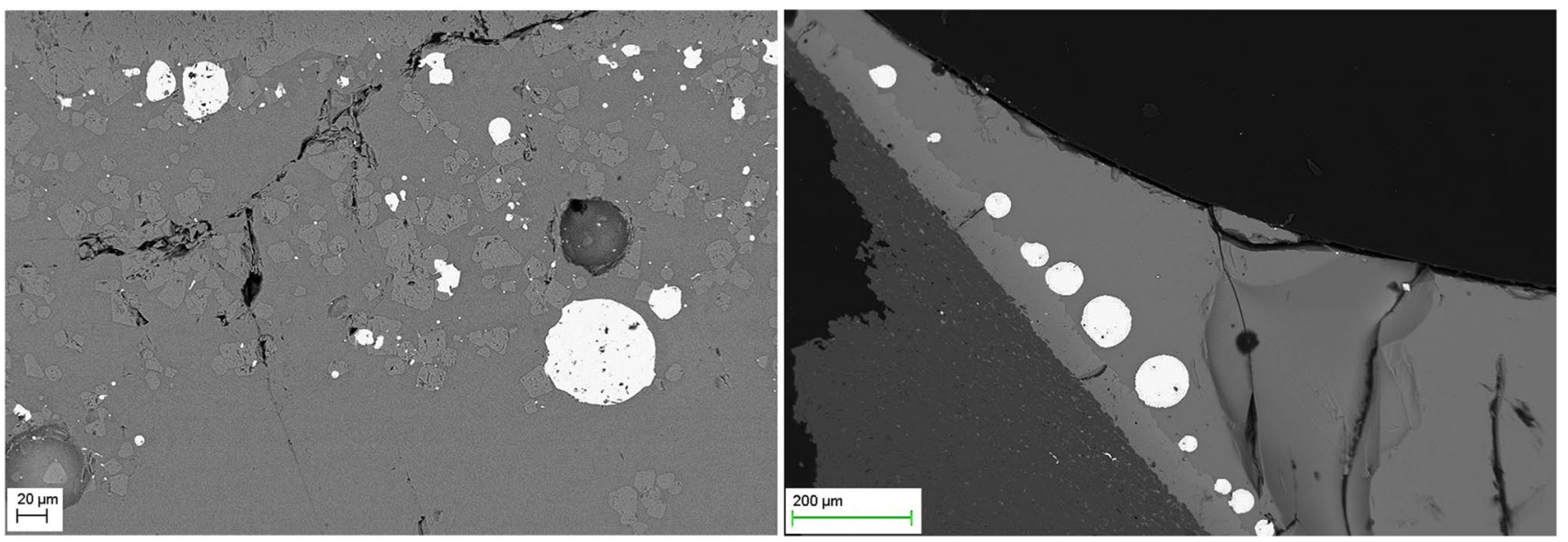

Fig. 13 Copper droplets trapped and adhered by spinel phase

the previous studies reporting $L^{C u / s}[P d]=10-10^{3}[25,40$, 43].

This study shows that if secondary copper feed includes high amounts of aluminum, precious metals can be recovered efficiently under black copper smelting conditions. Especially gold, platinum and palladium will be distributed very effectively $\left(L^{\mathrm{Cu} / \mathrm{s}}>10^{5}\right)$ on the copper's side, where they can be further recovered from anode slime [5]. Silver behavior was shown to be depended on the smelting atmosphere, $\mathrm{pO}_{2}$, and under reductive atmosphere, which typically is the first smelting stage, silver is recovered efficiently in the copper phase. The differences in results between our and previous studies can be due to different experimental conditions (atmosphere, temperature, slag composition). Moreover, the experimental technique varied between studies, and with the older techniques, quenching has not necessarily been rapid enough for achieving a homogenous phase structure compared to the modern technique [44]. Furthermore, the analyses have not been conducted with in-situ direct methods like EPMA and/or with highly sensitive techniques as LA-ICP-MS. This study provided concentration and distribution coefficient results based on the true chemical dissolution of precious metals in each phase, without risk of entrained phases distorting the results.

WEEE and copper scrap can be treated and fed into different smelting processes and process stages [5]. When compared to matte-smelting conditions, the recovery possibilities of precious metals ( $\mathrm{Au}, \mathrm{Pd}$ and $\mathrm{Pt}$ ) are better in black copper smelting (or converting) as the distribution coefficients between copper and alumina-containing slags are higher than between copper matte and iron-silicate slag [13]. In case of silver, the distribution coefficients in both of these smelting processes were shown to be in the same range. As a consequence of high distribution coefficients, the precious metals can be considered to be lost in copper processes mainly through mechanical copper/ matte droplet entrainment or operational reasons/errors. Solids in slags, such as spinels, increase droplet entrainment $[45,46]$. Figure 13 shows how copper droplets were attached to or trapped during equilibration between spinels in the slags, and adhered to the rim spinel in the present study. In copper processing conditions, spinel and other solid phase formation should be, therefore, avoided for maximizing copper and precious metal recoveries into the copper phase.

\section{Conclusions}

This investigation provided valuable new insight and results in the field of secondary copper smelting and copper manufacturing technologies. The main focus was to experimentally define the equilibrium distributions of gold, silver, platinum and palladium between copper and $\mathrm{FeO}_{\mathrm{x}}-\mathrm{SiO}_{2}-\mathrm{Al}_{2} \mathrm{O}_{3}(-\mathrm{CaO})$ slags in simulated black copper smelting conditions in the oxygen partial pressure range $10^{-5}-10^{-10} \mathrm{~atm}$ at $1300^{\circ} \mathrm{C}$. The equilibrium compositions of major elements in the phases of the investigated system were also presented. An advanced and very sensitive experimental method, a combination of equilibrationrapid quenching-EPMA/LA-ICP-MS direct phase analysis, was applied. The silver distribution coefficient increased from 10 to $10^{3}$ as a function of decreasing oxygen partial pressure. Gold distribution coefficients at $p O_{2}=10^{-5}$ atm was $2 \times 10^{5}$ and $4 \times 10^{5}$ for $\mathrm{CaO}$-free and $\mathrm{CaO}$-containing slags, respectively. Below $p O_{2}=10^{-6}$ atm, $\mathrm{L}^{\mathrm{Cu} / \mathrm{s}}[\mathrm{Au}]$ was essentially constant with values in the range of $10^{6}-10^{7}$. Platinum concentration in the slag was mainly below the detection limits of LA-ICP-MS for all laser spot sizes applied giving a minimum $L^{\mathrm{Cu} / s}[P t]$ of $10^{6}$. Palladium was observed to be very difficult to analyze reliably at such 
low concentrations in $\mathrm{Cu}$-rich systems by LA-ICP-MS. With corrected ${ }^{106} \mathrm{Pd}$ and ${ }^{108} \mathrm{Pd}$ slag results, the distribution coefficients were calculated as $10^{5}-10^{6}$. Initially, the copper alloy included $1 \mathrm{wt} \%$ of each precious metal, from which the resulting chemical solute concentrations in slags were roughly 10-500 ppmw for Ag, $<4$ ppbw (25-45 ppbw at $p O_{2}=10^{-5} \mathrm{~atm}$ ) for $\mathrm{Au},<6 \mathrm{ppbw}$ for Pt and $<40 \mathrm{ppbw}$ (50-80 ppbw at $p O_{2}=10^{-5}$ atm) for Pd. Lime addition improved silver recovery notably and had also a minor positive effect on the gold recovery into the copper alloy phase. Overall, all investigated precious metals can be recovered very efficiently in copper phase through secondary copper smelting and with high alumina-containing slags. The focus in smelting, to maximize the recoveries of precious metals, should be put in proper settling and phase separation.

Acknowledgements Open access funding provided by Aalto University. This research was financially supported by CLEEN Oy (Clic Innovation Oy), Kuusakoski Oy and Outotec as a part of ARVI project. The authors would like to thank the Finnish Cultural and Alfred Kordelin Foundations for financial support. The assistance of Lassi Pakkanen (GTK) in the EPMA analyses is greatly appreciated. This study utilized the Academy of Finland's RawMatTERS Finland Infrastructure (RAMI), based jointly at Aalto University, GTK Espoo and VTT Espoo.

Open Access This article is licensed under a Creative Commons Attribution 4.0 International License, which permits use, sharing, adaptation, distribution and reproduction in any medium or format, as long as you give appropriate credit to the original author(s) and the source, provide a link to the Creative Commons licence, and indicate if changes were made. The images or other third party material in this article are included in the article's Creative Commons licence, unless indicated otherwise in a credit line to the material. If material is not included in the article's Creative Commons licence and your intended use is not permitted by statutory regulation or exceeds the permitted use, you will need to obtain permission directly from the copyright holder. To view a copy of this licence, visit http://creativecommons.org/licenses/by/4.0/.

\section{References}

1. Chancerel P, Meskers CE, Hagelüken C, Rotter VS (2009) Assessment of precious metal flows during preprocessing of waste electrical and electronic equipment. J Ind Ecol 13(5):791-810

2. Cui J, Zhang L (2008) Metallurgical recovery of metals from electronic waste: a review. J Hazard Mater 158(2):228-256

3. Eurostat (2017). European Commission. https://ec.europa.eu/euros tat/web/waste/key-waste-streams/weee. Accessed 28 Aug 2017

4. Ghodrat M, Rhamdhani MA, Brooks G, Masood S, Corder G (2016) Techno economic analysis of electronic waste processing through black copper smelting route. J Clean Prod 126:178-190

5. Schlesinger ME, King MJ, Sole KC, Davenport WG (2011) Extractive metallurgy of copper, 5th edn. Elsevier, Oxford, $\mathrm{p} 455$

6. Pizzol M, Andersen MS, Thomsen M (2012) Greening of electronics. Danish ministry of the Environment, Project No. 1416, p 64

7. Veit HM, Bernardes AM, Ferreira JZ, Tenório JAS, de Fraga Malfatti C (2006) Recovery of copper from printed circuit boards scraps by mechanical processing and electrometallurgy. J Hazard Mater 137(3):1704-1709

8. Anindya A (2012) Minor elements distribution during the smelting of WEEE with copper scrap. Doctoral thesis. Civil, Environmental and Chemical Engineering, RMIT University. p 200

9. Outotec (2011) Secondary copper processing — a more sustainable solution. Output Australia, 29, pp9-11. https://www.outotec.com/ imagevaultfiles/id_567/cf_2/secondary_copper_processing.pdf. Accessed 21 Apr 2017

10. Avarmaa K, Yliaho S, Taskinen P (2017) Recovery possibilities of rare elements $\mathrm{Ga}, \mathrm{Ge}, \mathrm{In}$ and $\mathrm{Sn}$ from WEEE in secondary copper smelting. Waste Manage 71:400-410

11. Klemettinen L, Avarmaa K, Taskinen P (2017) Trace element distributions in black copper smelting. World of Metallurgy. ERZMETALL 70(5), 257-264.

12. Shuva MAH, Rhamdhani MA, Brooks GA, Masood S, Reuter MA (2016) Thermodynamics data of valuable elements relevant to e-waste processing through primary and secondary copper production: a review. J Clean Prod 131:795-809

13. Avarmaa K, O'Brien H, Johto H, Taskinen P (2015) Equilibrium distribution of precious metals between slag and copper matte at $1250-1350^{\circ}$ C. J Sustain Metall 1:216-228

14. Avarmaa K, Johto H, Taskinen P (2014) Distribution of precious metals ( $\mathrm{Ag}, \mathrm{Au}, \mathrm{Pd}, \mathrm{Pt}$, and $\mathrm{Rh}$ ) between copper matte and iron silicate slag. Metall Mater Trans B 47:244-255

15. Hidayat T, Fallah-Mehrjardi A, Chen J, Hayes P, Jak E (2016) Experimental study of metal-slag and matte-slag equilibria in controlled gas atmospheres. In Proceedings of the 9th International Copper Conference, Kobe, Japan. TMS, pp. 1332-1345

16. Roghani G, Takeda Y, Itagaki K (2000) Phase equilibrium and minor element distribution between $\mathrm{FeO}_{\mathrm{x}}-\mathrm{SiO}_{2}-\mathrm{MgO}$-based slag and $\mathrm{Cu}_{2} \mathrm{~S}-\mathrm{FeS}$ matte at $1573 \mathrm{~K}$ under high partial pressures of $\mathrm{SO}_{2}$. Metall Mater Trans B 31(4):705-712

17. Roghani G, Hino M, Itagaki K (1997) Phase equilibrium and minor element distribution between slag and copper matte under high partial pressures of $\mathrm{SO}_{2}$. In Proceedings of the 5th International Conference on Molten Slags, Fluxes and Salts, Sydney, Australia. Iron Steel Soc, Warrendale, pp. 693-703

18. Yamaguchi K (2010) Distribution of precious metals between matte and slag and precious metal solubility in slag. In Proceedings of the 7th International Copper Conference, Hamburg, Germany. GDMB, Clautshal-Zellerfeld, 3, pp. 1287-1295

19. Avarmaa K, O'Brien $\mathrm{H}$, Taskinen $\mathrm{P}$ (2016) Equilibria of gold and silver between molten copper and $\mathrm{FeO}_{\mathrm{x}}-\mathrm{SiO}_{2}-\mathrm{Al}_{2} \mathrm{O}_{3}$ slag in WEEE smelting at $1300^{\circ} \mathrm{C}$. In Proceedings of the 10 th International Conference on Molten Slags, Fluxes and Salts, Seattle, US. Springer Nature, Switzerland, 193-202

20. Tirronen T, Sukhomlinov D, Taskinen P (2017) Distribution of lithium-ion and nickel-metal hybride battery metals in copper converting. J Clean Prod 168:399-409

21. Griffin WL, Powell WJ, Pearson NJ, O'Reilly SY (2008) GLITTER: data reduction software for laser ablation ICP-MS. In: laser ablation-ICP-MS in the earth sciences: current practices and outstanding issues (P. Sylvester Edit.). Mineral. Assoc. Canada, Short Course Series, 40:308-311

22. Jochum KP, Weis U, Stoll B, Kuzmin D, Yang Q, Raczek I, Günther D (2011) Determination of reference values for NIST SRM 610-617 glasses following ISO guidelines. Geostand Geoanal Res 35(4):397-429

23. Jochum KP, Willbold M, Raczek I, Stoll B, Herwig K (2005) Chemical characterisation of the USGS reference glasses GSA1G, GSC-1G, GSD-1G, GSE-1G, BCR-2G, BHVO-2G and BIR$1 \mathrm{G}$ using EPMA, ID-TIMS, ID-ICP-MS and LA-ICP-MS. Geostand Geoanal Res 29(3):285-302

24. Chen JJ, Allen, C, Hayes PC, Jak E (2016) Experimental study of slag/matte/metal/tridymite four phase equilibria and minor 
elements distribution in "Cu-Fe-Si-SO" system by quantitative microanalysis techniques. In Proceedings of the 10th International Conference on Molten Slags, Fluxes and Salts, Seattle, US. Springer, Cham, pp. 961-970.

25. Nishijima W, Yamaguchi K (2014) Effects of slag composition and oxygen potential on distribution ratios of platinum group metals between $\mathrm{Al}_{2} \mathrm{O}_{3}-\mathrm{CaO}-\mathrm{SiO}_{2}-\mathrm{Cu}_{2} \mathrm{O}$ slag system and molten copper at $1723 \mathrm{~K}$. J Jpn Inst Met 78(7):267-273

26. Takeda Y, Roghani G (1993) Distribution equilibrium of silver in copper smelting system. In Proceedings of the 1st International Conference on Processing Materials for Properties, Hawaii. TMS, Warrendale, pp. 357-360

27. Kim HG, Sohn HY (1998) Effects of $\mathrm{CaO}, \mathrm{Al}_{2} \mathrm{O}_{3}$, and $\mathrm{MgO}$ additions on the copper solubility, ferric/ferrous ratio, and minorelement behavior of iron-silicate slags. Metall Mater Trans B 29(3):583-590

28. Sugiyama N (2015) Removal of complex spectral interferences on noble metal isotopes. Agilent 8800 ICP-QQQ Application Handbook, 47-51.

29. Sylvester PJ (2001) A practical guide to platinum-group element analysis of sulphides by laser-ablation ICPMS. In: PJ Sylvester (Ed.): Laser-ablation in the earth sciences: principles and application. Mineralogical Association of Canada, 203-213.

30. Taylor JR, Dinsdale AT (1993) A thermodynamic assessment of the Cr-Fe-O system. Zeitschrift fur Metallkunde 84(5):335-345

31. Strengell D, Avarmaa K, Johto H, Taskinen P (2016) Distribution equilibria and slag chemistry of DON smelting. Can Metall Q 55(2):234-242

32. Takeda Y, Ishiwata S, Yazawa A (1983) Distribution equilibria of minor elements between liquid copper and calcium ferrite slag. Trans Jpn Inst Metals 24(7):518-528

33. Swinbourne D (2005) Solubility of precious metals in slags. In Proceedings of the 3rd European Metallurgical Conference, Dresden, Germany. GDMB, Clausthal-Zellerfeld, 1, pp. 223-235.

34. Park JH, Min DJ (1999) Quantitative analysis of the relative basicity of $\mathrm{CaO}$ and $\mathrm{BaO}$ by silver solubility in slags. Metall Mater Trans B 30(4):689-694

35. Sukhomlinov D, Taskinen P (2017) Distribution of Ni, Co, Ag, $\mathrm{Au}, \mathrm{Pt}, \mathrm{Pd}$ between copper metals and silica saturated iron silicate slag. In Proceedings of the 9th European Metallurgical Conference, Leipzig, Germany. GDMB, Clausthal-Zellerfeld, 3, pp. 1029-1038.
36. Altman R, Kellogg H (1972) Solubility of $\mathrm{Cu}$ in silica-saturated iron silicate slag. Trans Inst Min Metall 81:163-175

37. Taylor JR, Jeffes JHE (1975) Activity of cuprous oxide in iron silicate slags of various compositions. Trans Inst Min Metall 84:C18-C24

38. Toguri JM, Santander NH (1972) Distribution of copper between $\mathrm{Cu}-\mathrm{Au}$ alloys and silica-saturated fayalite slags. Metall Mater Trans B 3(2):590-592

39. Swinbourne DR, Yan S, Salim S (2005) The solubility of gold in metallurgical slags. Miner Process Extr Metall 114(1):23-29

40. Yamaguchi K (2011) Distribution of platinum and palladium in iron oxide slags equilibrated with molten copper at $1573 \mathrm{~K}$. In Proceedings of the 6th European Metallurgical Conference, Düsseldorf, Germany. GDMB, Clausthal-Zellerfeld, 1, pp. 171-179.

41. Morita K, Wiraseranee C, Shuto H, Nakamura S, Iwasawa K, Okabe TH, Sano N (2014) Dissolution behaviour of platinum group metals into molten slags. Miner Process Extr Metall 123(1):29-34

42. Wiraseranee C, Yoshikawa T, Okabe TH, Morita K (2014) Dissolution behavior of platinum in $\mathrm{Na}_{2} \mathrm{O}-\mathrm{SiO}_{2}$-based slags. Mater Trans 55(7):1083-1090

43. Shuva MAH, Rhamdhani MA, Brooks GA, Masood SH, Reuter MA (2017) Thermodynamics of palladium (Pd) and tantalum (Ta) relevant to secondary copper smelting. Metall Mater Trans B 48(1):317-327

44. Jak E, Hayes PC (2004) Phase equilibria determination in complex slag systems. In Proceedings of the 7th International Conference on Molten Slags, Fluxes and Salts, Cape Town, South Africa. The South African Institute of Mining and Metallurgy, Johannesburg 36, pp. 85-104

45. De Wilde E, Bellemans I, Campforts M, Guo M, Vanmeensel K, Blanpain B, Verbeken K (2017) Study of the effect of spinel composition on metallic copper losses in slags. J Sustain Metall $3(2): 416-427$

46. De Wilde E, Bellemans I, Zheng L, Campforts M, Guo M, Blanpain B, Verbeken K (2016) Origin and sedimentation characteristics of sticking copper droplets to spinel solids in pyrometallurgical slags. Mater Sci Technol 32(18):1911-1924

Publisher's Note Springer Nature remains neutral with regard to jurisdictional claims in published maps and institutional affiliations. 